\title{
ANTIMICROBIAL AND ANTIOXIDANT POTENTIALS OF ENDOPHYTIC ACTINOMYCETES ISOLATED FROM LEAVES OF ASPHODELUS TENUIFOLIUS (CAV.) (MARSA MATROUH, EGYPT)
}

\author{
Dina M. Fahmy ${ }^{*}$, Nagwa M. Sidkey ${ }^{2}$, Mai Y. Elkawaga ${ }^{2}$ and \\ Doaa S. Zaid ${ }^{1}$ \\ ${ }^{1}$ Natural Product Unit, Department of Medicinal and Aromatic Plants, \\ Desert Research Center, El-Matareya, Cairo, Egypt \\ ${ }^{2}$ Department of Botany and Microbiology, Faculty of Science, Al- \\ Azhar University, Cairo, Egypt \\ *E-mail: dmfahmy@gmail.com
}

\begin{abstract}
7 he study aimed to evaluate the antimicrobial and antioxidant abilities of four endophytic actinomycetes (strain Act $_{1}$, Act $_{2}$, $\mathrm{Act}_{3}$, and $\mathrm{Act}_{4}$ ) isolated from leaves of Asphodelus tenuifolius, as well as assessment of their phytochemical profile. Referring to morphological characters and 16S rDNA sequence analysis, actinomycete (strain Act2) was identified as Streptomyces fenghuangensis (GIMN4.003T) with 96\% identical sequence and accession number (NR1175021). The results showed variant inhibitory activity against pathogenic bacteria and fungi. Act $_{2}$ endophytic actinomycete isolate showed broad spectrum activity against all pathogenic tested organisms, recording notable MIC value $10 \mu \mathrm{g} / \mathrm{ml}$ against Bacillus subtilus and Bacillus cereus, while $\mathrm{At}_{3}$ and $\mathrm{At}_{4}$ showed strong impact on Candida albicans. All of the ethyl acatate extracts of actinomycete isolates revealed high antioxidant activity ranging from $45-82 \%$ using DPPH radical. Phytochemical screening of the isolates indicates the presence of phenolics, flavonoids, sterols, anthraquinones and naphthaquinones.
\end{abstract}

Keywords: Asphodelus tenuifolius, antimicrobial, antioxidant, Streptomyces fenghuangensis, phytochemical screening

Endophytes are microorganisms that for the whole or part of their life live inside plant tissues by symbiotic, parasitic or mutualistic bond without causing overt bad effects (Stone et al., 2000). Based on these longheld associations, endophytes and plants have established good communication (Strobel, 2003). Medicinal plants synthesize chemical substances, providing raw material for pharmaceutical, cosmetic and health care industries (Berdy, 2012). Endophytic microorganisms in medicinal 
plant most likely participate in metabolic pathways of its host and produce analogous or novel bioactive compounds, for example taxol (Strobel et al., 1999). Endophytic actinomycetes produce a diverse range of secondary metabolites that play an essential role in pharmaceutical industry. Streptomyces is the largest antibiotic-producing genus, producing antibacterial (Castillo et al., 2006), antifungal (Taechowisan et al., 2005), and antiparasitic drugs, in addition to a wide range of other bioactive compounds, such asimmuno-suppressants (Muramatsu and Nagai, 2013) and antitumors (Igarashi et al., 2007). It is reported that total number of bioactive metabolites produced by microorganisms are around 23,000 out of which 10,000 ( $45 \%$ of all bioactive metabolites) are produced by actinomycetes alone, and among this group of bacteria, 7600 (76\%) compounds are reported from a single genus Streptomyces (Berdy, 2012). This clarifies their major importance in the world of pharmaceuticals.

Medicinal plants offer valuable therapeutic agents in traditional medicines. Asphodelus tenuifolius Cav. (family Liliaceae) is an annual, medicinal shrub, distributed widely in Northwestern coast Marsa Matrouh, Egypt. Seeds of Asphodelus tenuifolius are reported in traditional medicine to be diuretic, eaten with yoghourt and aids in healing wounds. The leaves are fried or boiled and are sometimes put in the sauce for couscous (Batanouny et al., 2005). Many previous researches focused on investigating endophytic actinomycetes in medicinal plants. As far of our knowledge no previous attempts have established on endophytic community in Asphodelus tenuifolius. This study aimed to isolate actinomycetes from leaves of $A$. tenuifolius and investigate their antimicrobial and antioxidant activities, and their bioactive metabolite.

\section{MATERIALS AND METHODS}

\section{Isolation of Endophytic Actinomycetes}

Endophytic actinomycetes were isolated from leaves of Asphodelus tenuifolius, collected from the Northwestern Coastal Region of Egypt, according to Saini et al. (2016).

The leaves of Asphodelus tenuifolius were sterilized using 5\% (w/v) sodium hypochlorite. The sterilized leaves were cut into small pieces (0.5$1.0 \mathrm{~cm}$ ) and placed on starch casein agar plates (SCA) supplemented with antifungal nystatin $(50 \mu \mathrm{g} / \mathrm{ml})$. Plates were incubated at $28^{\circ} \mathrm{C}$ for 14 days under observation of the growth of endophytic actinomycetes. The obtained actinomycetes isolates were purified then stored at $4^{\circ} \mathrm{C}$ for further investigations.

\section{Screening and Extraction of Actinomycetes Cultures}

The spore suspension of actinobacteria were extracted according to Devi et al. (2012). Briefly, $1 \mathrm{ml}$ of each spore suspension was inoculated 
into $300 \mathrm{ml}$ starch casein broth in Erlenmeyer flasks, and incubated under shaking $(200 \mathrm{rpm})$ at $37^{\circ} \mathrm{C}$ for 7 days. Each culture broth was filtered to separate spore and mycelial mass. Filtrates were centrifuged at $5000 \mathrm{rpm}$ for $10 \mathrm{~min}$. then the clear supernatants (culture broth) were transferred to sterile conical flaks and stored at $-20^{\circ} \mathrm{C}$ for further screening.

The culture filtrates were extracted using ethyl acetate $(3 \times 200 \mathrm{ml})$ by partitioning in a separating funnel. The ethyl acetate extract (AtEAc) of each isolate was concentrated under reduced pressure at $45^{\circ} \mathrm{C}$ using rotary evaporator (Buchi, Switzerland). The AtEAc extracts were kept at $4^{\circ} \mathrm{C}$ until being used.

\section{Characterization of Actinomycetes Isolates}

Endophytic actinomycetes isolates were characterized based on colony morphology after 14 days of incubation. The morphological characteristics of the isolates were examined according to the Bergey's Manual of Determinative Bacteriology (Holt et al., 1994). Scanning electron microscope (SEM) was used to obtain images of selected isolates. Living specimens were processed and examined by the procedures described previously (Ezra et al., 2004). 16S rDNA sequence analysis was executed to identify the active isolate

\section{16S rDNA Gene Amplification and Sequencing}

The identity of the active actinomycetes was determined based on partial or nearly full length $16 \mathrm{~S}$ rRNA gene sequence analysis. The genomic DNA of $\mathrm{At}_{2}$ isolate was extracted by using a protocol of Thermo Scientific Gene JET Genomic DNA Purification Kit (ThermoK0721). 16S rRNA amplification was achieved by Polymerase Chain Reaction (PCR) technique using Maxima Hot Start PCR Master Mix kit (ThermoK1051). To $50 \mu 1$ of the sample, $25 \mu \mathrm{l}$ of Maxima Hot Start PCR Master Mix (2X), $1 \mu 1(20 \mu \mathrm{m})$ of forward primer (AGA GTT TGA TCC TGG CTC AG), $1 \mu 1(20 \mu \mathrm{m})$ of reverse primer (GGT TAC CTT GTT ACG ACT T), $5 \mu 1$ Taq DNA polymerase, and $18 \mu \mathrm{l}$ water, nuclease-free were added. The sample was gently vortexed, then subjected to perform PCR using the following thermal cycling conditions: initial denaturation/enzyme activation at $95^{\circ} \mathrm{C}$ for $10 \mathrm{~min}$ ( 1 cycle), denaturation at $95^{\circ} \mathrm{C}$ for $30 \mathrm{~s}\left(35\right.$ cycles), annealing at $65^{\circ} \mathrm{C}$ for 1 min ( 35 cycles), extension at $72^{\circ} \mathrm{C}$ for $1 \mathrm{~min}$ and $30 \mathrm{~s}$ (35 cycles), final extension at $72^{\circ} \mathrm{C}$ for $10 \mathrm{~min}(1 \mathrm{cycle})$.

PCR products were purified according to the protocol described in the manual of Gene JET PCR Purification Kit (ThermoK0701). The quality of the purified DNA was evaluated spectrophotometrically, by agarose gel electrophoresis. Finally, sequencing was achieved on GATC biotech Company (Germany) and sequenced with an automated capillary DNA sequencing system (ABI 3730). 


\section{Screening of the Antimicrobial Activity of Crude Extracts}

Antimicrobial activity of the crude extract (culture filtrate) of actinomycetes was determined against pathogenic gram positive bacteria (Bacillus subtilus, Bacillus cereus, Staphylococcus aureus), gram negative bacteria (Escherichia coli, Salmonella typhi and Klebsiella pneumoniaea) as well as fungal pathogens (Candida albicans and Aspergallus niger) using agar well diffusion method (Tawde et al., 2012).

Plates of Mueller Hinton Agar were inoculated with a volume of 0.1 $\mathrm{ml}$ of each of bacterial suspension $\left(4 \times 10^{6} \mathrm{CFU} / \mathrm{ml}\right)$ as well as fungal suspension $\left(2 \times 10^{6} \mathrm{CFU} / \mathrm{ml}\right.$. Fixed volumes $(100 \mu \mathrm{l})$ of the crude extract were aseptically dropped into wells $(5 \mathrm{~mm}$ diameter) made in culture media. Water without extract was used as control. Cefotaxime $(30 \mu \mathrm{g} / \mathrm{ml})$, Ampicillin sulbactam $(20 \mu \mathrm{g} / \mathrm{ml})$, and Fluconazol $(100 \mu \mathrm{g} / \mathrm{ml})$ were used as reference antimicrobial agents. Plates were incubated at $37^{\circ} \mathrm{C}$ for $24 \mathrm{~h}$ for bacteria and $28^{\circ} \mathrm{C}$ for fungi. The diameters of zones of inhibitions were measured.

\section{Determination of Minimum Inhibitory Concentration of Ethyl Acetate Extract}

Minimum inhibitory concentration (MIC) of Act $_{2}$ EAc extract, which displayed the strongest antimicrobial activity was determined using broth dilution method (Jahan et al., 2011). Briefly, $100 \mu \mathrm{l}$ of each tested organism, adjusted to $0.5 \mathrm{McF}$ arland units (about $10^{5} \mathrm{CFU} / \mathrm{ml}$ ), was aseptically inoculated into tubes containing equal volumes of serially diluted Act $_{2}$ EAc extract concentrations ( 5 to $200 \mu \mathrm{g} / \mathrm{ml}$ ) in Muller Hinton broth medium. The tubes were incubated for $24 \mathrm{~h}$ at $37^{\circ} \mathrm{C}$. The lowest concentration that produced no visible turbidity after full incubation period was regarded as MIC.

\section{Free Radical Scavenging Assay}

Free radical scavenging assay was carried out using 2, 2-diphenyl-1picryl hydrazyl (DPPH) reagent according to Yildirim et al. (2001). Dry extract of ActEAc was solubilized in $80 \%$ ethyl alcohol $(1000 \mu \mathrm{g} / \mathrm{ml})$. A volume of $3 \mathrm{ml}$ from each extract mixed with $1 \mathrm{ml}$ of $1 \mathrm{mM}$ of DPPH radical alongside with ascorbic acid $(1000 \mu \mathrm{g} / \mathrm{ml})$ as positive control. The tubes were kept at room temperature in the dark for $30 \mathrm{~min}$. The degree of disappearance of purple color was measured against blank $(80 \%$ ethyl alcohol) at $517 \mathrm{~nm}$. Data achieved in triplicate and results expressed in percentage.

\section{Free radical scavenging activity}

$$
=((\text { A blank }- \text { A sample }) /(\text { A blank })) X 100
$$

Where, A blank is the absorbance of the control reaction (containing all reagents except the test compound), and A sample is the absorbance of the test compound. 


\section{Phytochemical Analysis}

Preliminary active compound profile was established for ethyl acetate extract (ActEAc). Tests were performed to detect the presence of saponines, naphthaquinones, glycoside, phenolics, steroids, anthraquinones, and flavonoids as described by Thomson (1997) and Harborne (1998).

\section{RESULTS}

\section{Isolation of Endophytic Actinomycetes}

Four endophytic actinomycetes (Act) were morphologically recognized in Starch casein agar solid medium spreading with leaf segments of A. teniufolius after 14 days of incubation (Fig. 1 and 2). During incubation, the green colour of leaves turned to brown and the colonies of actinomycetes emerged on the cut leaf margins. The colour of the spore mass was grey, and the strain produced white aerial mycelium and yellow to yellowish-white vegetative mycelium.

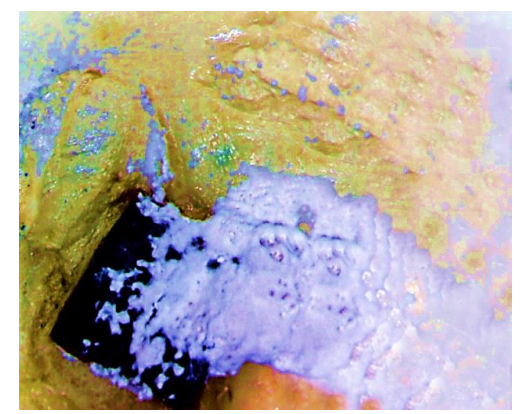

Fig. (1). Actinomycete emerge out of leaf margin on starch casein agar plate.

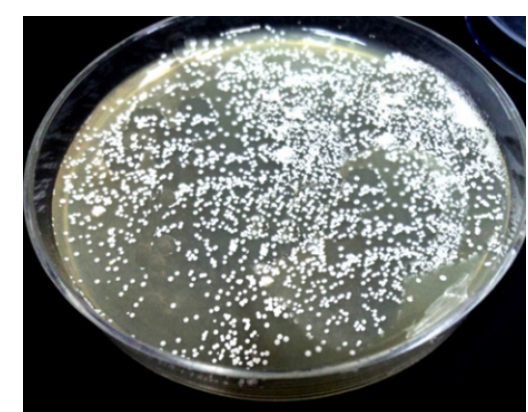

Fig. (2). Actinomycete growth on starch casein agar plate showing regular rounded colony with white aerial mass color and yellow substrate mycelium.

\section{Antimicrobial Activity of Crude Extracts}

Fermentation process was undertaken to propagate isolates and prepare the crude extract of each isolate. Antimicrobial potency of actinomycetes isolates was experienced against pathogenic bacteria and fungi. Data in table (1) reveal that $100 \mu 1$ crude extract of Act 2 proved potent antimicrobial potential against all tested Gram-positive and Gram-negative bacteria, and fungal pathogen. Act $1, \mathrm{Act}_{3}$, and $\mathrm{Act}_{4}$ recorded no inhibition effect against both Gram-positive and Gram-negative bacteria. Concerning fungal inhibition potential, Act 3 and $\mathrm{Act}_{4}$ showed moderate antifungal activity. According to the attained data, the Act ${ }_{2}$ EAc extract showed relatively maximal activity against Gram positive B. cereus and B. subtilis 
(recording MIC of $10 \mu \mathrm{g} / \mathrm{ml}$ for both), when compared with Cefotaxime (30 $\mu \mathrm{g} / \mathrm{ml})$ that record 30 and $20 \mu \mathrm{g} / \mathrm{ml}$ against both strains, respectively, and Ampicillin $(20 \mu \mathrm{g} / \mathrm{ml})$ that record no activity against $B$. cereus and $B$. subtilis. In contrary to Cefotaxime $(30 \mu \mathrm{g} / \mathrm{ml})$ and Ampicillin $(20 \mu \mathrm{g} / \mathrm{ml})$, $\mathrm{Act}_{2} \mathrm{EAc}$ presented challenging pattern against Gram negative E. coli, $K$. pneumoniaea, and S. typhi recording MIC 125, 125 and $200 \mu \mathrm{g} / \mathrm{ml}$, respectively. Comparatively, Act ${ }_{2}$ Ac extract exhibited potent antifungal effect against $C$. albicans and A. niger with MIC 25 and $75 \mu \mathrm{g} / \mathrm{ml}$, respectively, when evaluated by control fluconazole $(100 \mu \mathrm{g} / \mathrm{ml})$ (table 2$)$.

Table (1). Antimicrobial screening on crude extract of isolated endophytic actinomyctes from leaves of $A$. tenuifolius against pathogenic bacteria and fungi.

\begin{tabular}{lcccc}
\hline \multirow{2}{*}{$\begin{array}{l}\text { Pathogenic } \\
\text { microorganism }\end{array}$} & \multicolumn{4}{c}{ Diameter of Inhibition Zone (mm) } \\
\cline { 2 - 5 } & $\mathbf{A c t}_{\mathbf{1}}$ & $\mathbf{A c t}_{\mathbf{2}}$ & Act $_{\mathbf{3}}$ & Act $_{\mathbf{4}}$ \\
\hline Escherichia coli & - & 20 & - & - \\
Klebsiella pneumoniae & - & 25 & - & - \\
Salmonella typhi & - & 25 & - & - \\
Staphylococcus aureus & - & 27 & - & - \\
Bacillus subtilus & - & 30 & - & - \\
Bacillus cereus & - & 30 & - & - \\
Candida albicans & - & 23 & 17 & 19 \\
Aspergallus niger & - & 25 & - & - \\
\hline
\end{tabular}

Table (2). Minimum inhibitory concentration of ethyl acetate extract of $\mathrm{Act}_{2}$ $\left(\mathrm{Act}_{2} \mathrm{EAc}\right)$ against pathogenic microorganisms.

\begin{tabular}{|c|c|c|c|c|c|c|c|c|}
\hline \multirow[t]{2}{*}{ Extract } & \multicolumn{8}{|c|}{ MIC $(\mu \mathrm{g} / \mathrm{ml})$} \\
\hline & $\begin{array}{c}E . \\
\text { coli }\end{array}$ & $\begin{array}{c}\text { K. } \\
\text { pneumoniaea }\end{array}$ & $\begin{array}{c}S . \\
\text { typhi }\end{array}$ & $\begin{array}{c}S . \\
\text { aureus }\end{array}$ & $\begin{array}{c}\text { B. } \\
\text { subtilus }\end{array}$ & $\begin{array}{c}\text { B. } \\
\text { cereus }\end{array}$ & $\begin{array}{c}C . \\
\text { albicans }\end{array}$ & $\begin{array}{c}A . \\
\text { niger }\end{array}$ \\
\hline Act2EAc & 125 & 125 & 200 & 75 & 10 & 10 & 25 & 75 \\
\hline Cefotaxime & 30 & $\mathrm{R}$ & $\mathrm{R}$ & 30 & 30 & $\mathrm{R}$ & - & - \\
\hline Ampicillin & 20 & $\mathrm{R}$ & 20 & 20 & 20 & $\mathrm{R}$ & - & - \\
\hline Fluconazol & - & - & - & - & - & - & 100 & 100 \\
\hline
\end{tabular}

R: resistance, Cefotaxime (30 $\mu \mathrm{g} / \mathrm{ml})$, Ampicillin sulbactam $(20 \mu \mathrm{g} / \mathrm{ml})$, Fluconazole $(100 \mu \mathrm{g} / \mathrm{ml})$

\section{Phytochemical Profile}

Phytochemical screening achieved on ethyl acetate extracts (Table

3) showed the presence of phenolics and flavonoids in Act ${ }_{1} \mathrm{EAc}, \mathrm{Act}_{2} \mathrm{EAc}$, 
Act $_{3} E A c$, and $A_{c t} E A c$. Anthraquinones were represented in $A_{c t} E A c$ and Act $_{4}$ EAc.

Table (3). Phytochemical screening of bioactive compound in Act $_{2}$ EAc.

\begin{tabular}{lcccc}
\hline $\begin{array}{l}\text { Biological active } \\
\text { compounds }\end{array}$ & Act $_{1} \mathbf{E A c}$ & Act $_{2} \mathbf{E A c}$ & Act $_{3} \mathbf{E A c}$ & Act $_{4} \mathbf{E A c}$ \\
\hline Anthraqinones & - & - & + & + \\
Fatty acids & - & - & - & - \\
Flavonoids & ++ & ++ & + & + \\
Glycosides & - & - & - & - \\
Naphthaquinone & - & - & - & - \\
Phenolics & + & + & + & + \\
Saponines & - & - & - & - \\
Sterols & + & + & - & - \\
\hline
\end{tabular}

Strongly present (++), present (+), absent (-)

\section{Free Radical Scavenging Activity}

Regarding to free radical scavenging potential of ethyl acetate extracts of endophytic actinomycetes, DPPH radicals, after $30 \mathrm{~min}$ of incubation, were scavenged by 68 to $82 \%$. As shown in fig. (3), in comparison with ascorbic acid $(1000 \mu \mathrm{g} / \mathrm{ml})(92 \%)$. Act ${ }_{2}$ EAc succeeded in chelating maximally $82 \%$ of DPPH radical, displaying relatively potent radical chelation potential.

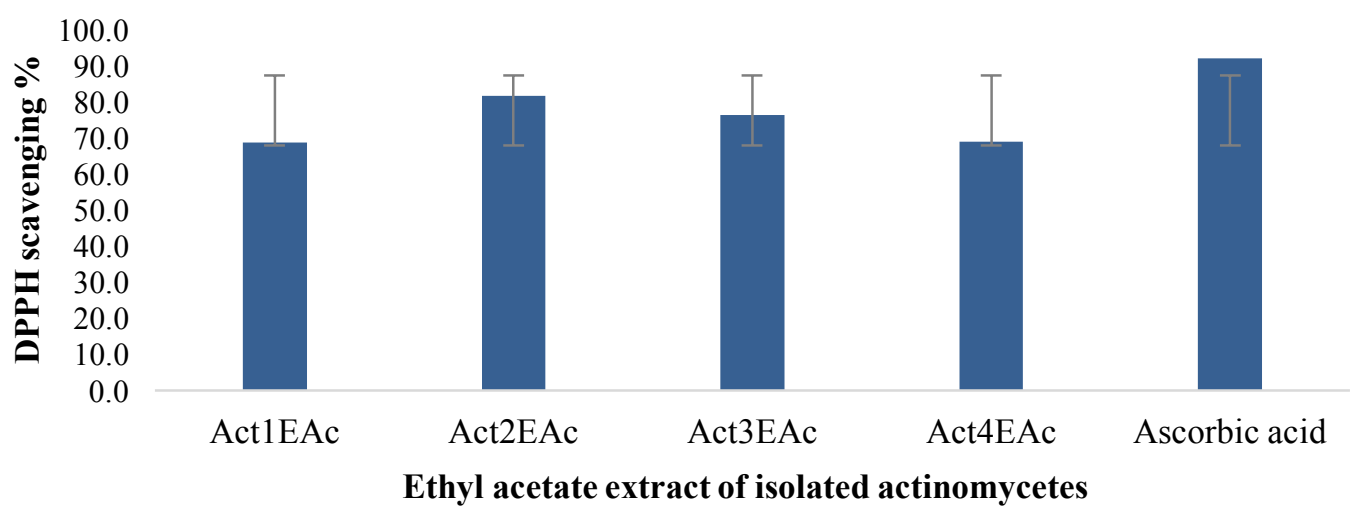

Fig. (3). DPPH scavenging activity of ethyl acetate extracts of isolated Streptomyces (ActEAc) and ascorbic acid as control, date represented as mean $\pm \mathrm{SD}$. 


\section{Identification of Actinomycete}

Isolate $\mathrm{Act}_{2}$ had morphological characteristics of the genus Streptomyces. SEM studies revealed a straight to flexuous mycelium without verticils. The aerial mycelium produced straight to flexuous spore chains. Act2 appeared to have characteristic streptomycete features (spore formation). Spores were rough to warty (Fig. 4). A partial 16S rRNA gene sequence was determined for isolate $\mathrm{Act}_{2}$. Sequence comparison with representatives of the family Streptomycetaceae confirmed that strain $\mathrm{Act}_{2}$ is closely related to members of the genus Streptomyces. It was 94-96\% similar to the 16S rRNA gene sequences of Streptomyces species. As shown in table (4), high 16S rRNA gene sequence similarity was found with Streptomyces fenghuangensis, (GIMN4.003T, 96\% similarity over 1613 bases), Streptomyces nanhaiensis (SCSIO 01248, 96\% similarity over 1596 bases), and Streptomyces radiopugnans (R97, 96\% similarity over 1591 bases).

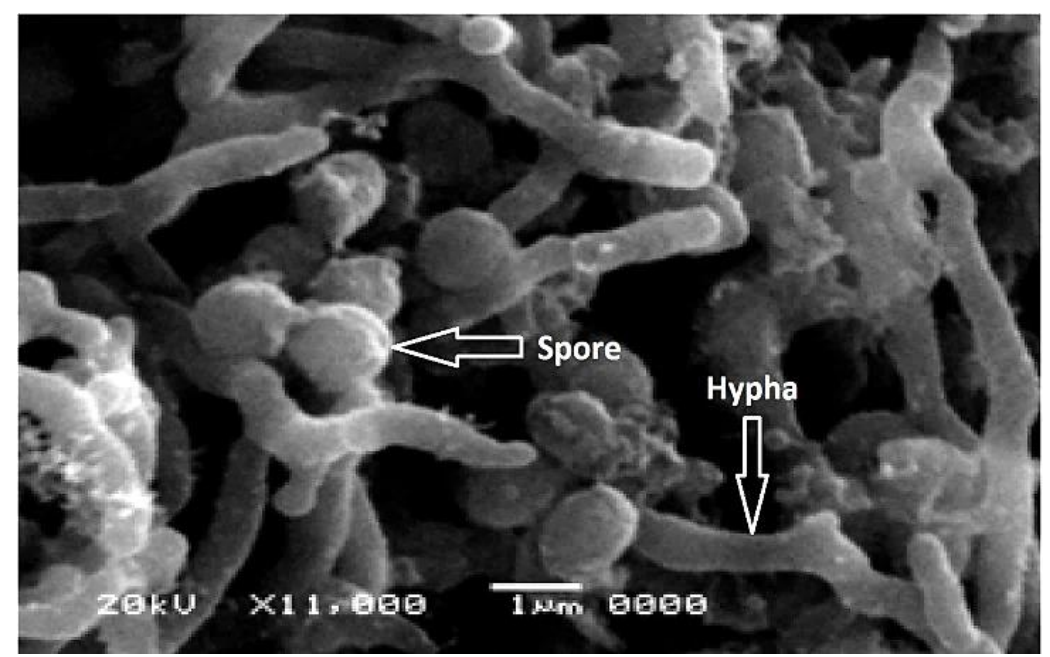

Fig. (4). Scanning electron micrographs of strain GIMN4.003T showing straight to flexuous (rectiflexibiles) spore chains of rough to warty spores after growth on Starch casein agar for 21 days at $28^{\circ} \mathrm{C}$.

Egyptian J. Desert Res., 66, No. 2, 373-386 (2016) 
Table (4). Identification of endophytic actinomycete Act $_{2}$ isolated from $A$. tenuifolius leaves based on 5' partial 16S rRNA sequences.

\begin{tabular}{|c|c|c|c|c|c|c|}
\hline Description & $\begin{array}{c}\text { Max } \\
\text { score }\end{array}$ & $\begin{array}{l}\text { Total } \\
\text { score }\end{array}$ & $\begin{array}{c}\text { Query } \\
\text { cover } \\
(\%)\end{array}$ & $\begin{array}{c}E \\
\text { value }\end{array}$ & $\begin{array}{c}\text { Ident } \\
(\%)\end{array}$ & Accession \\
\hline Streptomyces fenghunangensis strain GIMN4 00316 S ribosomal RNA gene partial sequence & 1613 & 1613 & 84 & 0 & 96 & NR 1175021 \\
\hline Streptomyces nanhaiensisstrain SCSIO 0124816 S ribosomal RNA gene partial sequence & 1596 & 1596 & 84 & 0 & 96 & NR 1086331 \\
\hline Streptomyces radiopugnans strain R97 165 ribosomal RNA gene partial sequence & 1591 & 1591 & 84 & 0 & 96 & NR 0440131 \\
\hline Streptomyces atcacamensis strain C6016S ribosomal RNA gene partial sequence & 1568 & 1568 & 84 & 0 & 95 & NR 1088591 \\
\hline Streptomyces atacamensis strain C60 16 S ribosomal RNA gene partial sequence & 1550 & 1550 & 84 & 0 & 95 & NR 1163561 \\
\hline Streptomyces barkulensis strain RC 1831 16S ribosomal RNA gene partial sequence & 1535 & 1535 & 84 & 0 & 95 & NR 1338691 \\
\hline Streptomyces megasportus strain NBBC 1474916 SS ribosomal RNA gene partial sequence & 1535 & 1535 & 84 & 0 & 95 & NR 0411651 \\
\hline Streptomyces macrosporpurus strain NBRC 14748165 ribosomal RNA gene partial sequence & 1535 & 1535 & 84 & 0 & 95 & NR 1124411 \\
\hline Streptomyces macrosporus strain A 1201165 ribosomal RNA gene partial sequence & 1520 & 1520 & 84 & 0 & 94 & NR 0265301 \\
\hline Streptomyces glaucosporus strain NBRC 1541616 S ribosomal RNA gene partial sequence & 1500 & 1500 & 84 & 0 & 94 & NR 0411811 \\
\hline Streptomyces thermolineatus strain NBRC 1475016 S ribosomal RNA gene partial sequence & 1496 & 1496 & 84 & 0 & 94 & NR 1124421 \\
\hline Streptomyces thermolineatusstrain Al484 165 ribosomal RNA gene partial sequence & 1491 & 1491 & 84 & 0 & 94 & NR 0265291 \\
\hline Streptomyces morookiaense strain CSSP70716S ribosomal RNA gene partial sequence & 1487 & 1487 & 84 & 0 & 94 & NR 1154301 \\
\hline
\end{tabular}

\section{DISCUSSION}

In this study, four strains of endophytic actinomycetes were isolated from leaves of Asphodelus tenuifolius that were collected from the Northwestern Coast, Egypt. Endemic plants in desert habitat exposed to difficult ecological conditions of high temperature, water scarcity and poor nutrition of sandy soil necessary for the development of plant. This desert habitat and its flora led to a significant variation in the endophytic microbial communities and their biological properties (Banerjee, 2011).

The study explored that, leaves of $A$. tenuifolius are inhabited by actinomycetes. In this context, the results are in line with that achieved by Saini et al. (2016), where out of the 50 endophytic isolates from different organs only one isolate yielded from leaf segment of Syzygium cumini. Similar trend was observed by other previous researchers, where Phuakjaiphaeo and Kunasakdakul (2015) reported that after 4 weeks of incubation at $30^{\circ} \mathrm{C}$, only 4 out of 36 isolates of endophytic actinomycetes were obtained from leaf part of Centella asiatica. According to Saini et al. (2016), successful achievement of endophytic actinomycetes isolation from leaves of $A$. tenuifolius was strong evidence on success of the surface sterilization procedures. As he declared that, the epiphytic microbes are completely removed by $5 \%$ sodium hypochlorite, which is frequently used in plant surface sterilization procedures. Besides, Nystatin supplement (50 
$\mu \mathrm{gl} / \mathrm{ml})$ in the starch casein agar, which inhibits the growth of fungi and other bacteria aids in establishing suitable settings to isolate and characterize endophytic actinomycetes.

In this work, the best antimicrobial action as evaluated by MIC value was achieved by $\mathrm{Act}_{2} \mathrm{EAc}$, which was the most active isolate against aggressive Gram positive $S$. aureus, B. cereus and B. subtilus with MIC $75,10,10 \mu \mathrm{g} / \mathrm{ml}$, respectively. Referring to phytochemical screening data, Act $_{2}$ EAc enclosed terpenoids, flavonoids and phenolics (Table 2), all of them reported to be antimicrobial agents (Mousa and Raizada, 2013). Consequently, antibacterial and antifungal potential may be attributed to the production of biologically active compounds in media. In harmony with Machavariani et al. (2014), who obtained 179 endophytic actinomycete isolates from leaf tissues of 20 medicinal plants. Out of these, 47 isolates were displaying antibacterial activity against $S$. aureus FDA209 P, 55 against $S$. aureus 209P/UF-2, 41 against $S$. aureus (MRSA) and 13 isolates were active against $E$. coli.

Research on the biological properties of actinomycetes has shown that these bacteria are prospective candidates to produce antifungal compounds, where Bachiega et al. (2005) reported that $20.3 \%$ of the actinomycete isolates studied was active against $C$. albicans. More recently, Gandotra et al. (2012) found that $33.3 \%$ of Streptomyces analyzed showed high degree of activity against Candida isolates. In accordance with former studies, 75\% (3/4) of the actinomycete isolates (Act Act $_{3}$ and $\mathrm{Act}_{2}$ ) showed antifungal activity against $C$. albicans with variant potency (Table 1). Act ${ }_{2}$ EAc recorded MIC value of $25 \mu \mathrm{g} / \mathrm{ml}$ regarding inhibition of C. albicans growth. Compared to results reported elsewhere, this proportion is comparatively high, and shows good promise for discovering and production of bioactive compounds that inhibit Candida albicans.

The bioactive potential of the potent strains was extended by testing their chelation potential against DPPH radicals. In comparison with ascorbic acid, ethyl acetate crude extracts possessed promising antioxidant activity via chelation free radicals, particularly, Act $_{2}$ EAc (Fig. 1). According to the phytochemical screening established in table (2), ActEAc presented a great proportion of phenolics and flavonoids as a part of the bioactive compounds pool. Moreover, ethyl acetate is often used as an extracting solvent with a significant selectivity in the extraction of low-molecular-weight phenolic compounds and high molecular-weight polyphenols. Conde et al. (2008) declared that ethyl acetate allowed the highest phenolic content and the selective removal of nonphenolic compounds. Thus, the antioxidant activity of ActEAc may be attributed to the presence of phenolic compounds in the extracts, whereas, there is a well-established significant correlation between phenolic compounds and antioxidant properties of medicinal plants (Baghiani et al., 2010 and Khennouf et al., 2010). The same pattern was seen in studies on endophytes as proved by Yadav et al., (2014), where the study 
attributed the antioxidant power of endophytic fungi isolated from Eugenia jambolana to the natural phenolic and flavonoid compounds.

$\mathrm{Act}_{2}$ as proved by $16 \mathrm{~S}$ rRNA gene sequence analysis, was strongly identified as Streptomyces fenghuangensis, (GIMN4.003T). Moreover, morphological features of $\mathrm{Act}_{2}$ as declared from scanning electron micrograph were identical to that described by Zhu et al. (2011). It is worth to mention, Streptomyces fenghuangensis, (GIMN4.003T), for the first time was isolated from medicinal plant whereas, it was isolated before from sea water by Zhu et al. (2011). Genus Streptomyces is a promising source of biological active materials with broad biological action as Streptomyces Tc052 and Streptomyces displayed antioxidant activity (Taechowisan et al., 2009). Likewise, S. aureofaciens CMUAc130 exhibited anti-inflammatory and antitumor potency (Taechowisan et al., 2007), also Taechowisan et al. (2005) declared that Streptomyces aureofaciens CMUAc130 presented antifungal activity. In 2014, Tanvir et al. reported that Streptomyces albovinaceus and S. badius are insecticidal.

In conclusion, data revealed four endophytic actionmycetes that were isolated from leaves of A. tenuifolius. Act2 was identified as Streptomyces fenghuangensis (GIMN4.003T). Streptomyces fenghuangensis (GIMN4.003T) exerted a promising antimicrobial and antioxidant activity that may be accredited to the presence of phenolics and flavonoids as shown by phytochemical profile investigation. Regarding the value of Streptomyces, more contributions in isolation of active compounds and studying their bioactivities is recommended.

\section{REFERENCES}

Bachiega, G.L., W. Vilegas and K. Ujikawa (2005). Antifungal antibiotic produced by a streptomycete from the region of Araraquara. Journal of Basic and Applied Pharmaceutical Sciences, 26 (1): 29-37.

Baghiani, A., S. Boumerfeg, F. Belkhiri, S. Khennouf, N. Charef, D. Harzallah, L. Arrar and M.A. Abdel-Wahhab (2010). Antioxidant and radical scavenging properties of Carthamus caeruleus L. extracts grow wild in Algeria flora. Comunicata Scientiae, 1 (2): $128-136$.

Banerjee, D. (2011). Endophytic fungal diversity in tropical and subtropical plants. Res. J. Microbiol, 6: 54-62.

Batanouny, K., F. Abdul Rahman, S. Benhouhou et al. (2005). In "A guide to Medicinal Plants in North Africa". Published by IUCN Centre for Mediterranean Cooperation, Malaga, Spain.

Berdy, J. (2012). Thoughts and facts about antibiotics: where we are now and where we are heading. J. Antibiot., 65: 385-395.

Egyptian J. Desert Res., 66, No. 2, 373-386 (2016) 
Castillo, U.F., G.A. Strobel, K. Mullenberg et al. (2006). Munumbicins E-4 and E-5: novel broad-spectrum antibiotics from Streptomyces NRRL 3052. FEMS Microbiol Lett., 255: 296-300.

Conde, E., A. Moure, H. Domınguez and J.C. Parajo (2008). Fractionation of antioxidants from autohydrolysis of barley husks. J. Agric. Food Chem., 56: 10651-10659.

Devi, S.C., J.S. Naine, N. Nasimunislam, B. Vaishnavi and V. Mohanasrinivasan (2012). Isolation of soil actinomycetes inhabiting amrithi forest for the potential source of bioactive compounds. Asian Journal of Pharmaceutical and Clinical Research, 5: 4-7.

Ezra, D., U. Castillo, G.A. Strobel et al. (2004). Coronamycins, peptide antibiotics produced by a verticillated Streptomyces sp. (MSU-2110) endophytic on Monstera sp. Microbiology, 150: 785-793.

Gandotra, S., G.R. Bisht and B.S. Saharan (2012). Antifungal activity of endophytic actinomycetes (Streptomyces) against Candida species. Int. J. Microbial Resource Technol., 1: 375-378.

Harborne, J.B. (1998). In "Phytochemical Methods" $3{ }^{\text {rd }}$ Edition. Chapman Hall, London, pp. 60-66.

Holt, J.G., N.R. Krieg, P.H.A. Sneath, J.T. Staley and S.T. Williams (1994). In "Bergey's Manual of Determinative Bacteriology". $9^{\text {th }}$ ed., Baltimore, Williams and Wilkins.

Igarashi, Y., M.E. Trujillo, E. Martínez-Molina et al. (2007). Antitumor anthraquinones from an endophytic actinomycete Micromonospora lupini sp. nov. Bioorg Med. Chem. Lett., 17: 3702-3705.

Jahan, F., R. Lawrence, V. Kumar and M. Junaid (2011). Evaluation of antimicrobial activity of plant extracts on antibiotic susceptible and resistant Staphylococcus aureusstrains. J. Chem. Pharm. Res., 3: 777789.

Khennouf, S., N. Iratni, A. Baghiani, D. Harzallah and L. Arrar (2010). Antioxidant and antibacterial activities of extracts from Artemisia herba alba Asso leaves and some phenolic compounds. J. Med. Plant Res., 4 (13): 1273-1280.

Machavariani, N.G., T.D. Ivankova, O.N. Sineva and L.P. Terekhova (2014). Isolation of endophytic actinomycetes from medicinal plants of the Moscow Region Russia. World Appl. Sci. J., 30: 1599-1604.

Mousa, W.K. and M.N. Raizada (2013). The diversity of anti-microbial secondary metabolites produced by fungal endophytes: an interdisciplinary perspective. Front Microbiol., 4: 1-18.

Muramatsu, H. and K. Nagai (2013). Streptomyces tsukubensis sp. nov., a producer of the immunosuppressant tacrolimus. J. Antibiot., 66 (4): 251-4.

Phuakjaiphaeo, C. and K. Kunasakdakul (2015). Isolation and screening for inhibitory activity on Alternaria brassicicola of endophytic

Egyptian J. Desert Res., 66, No. 2, 373-386 (2016) 
actinomycetes from Centella asiatica (L.) Urban. Int. J. Agric. Technol., 11: 903-912.

Saini, P., M. Gangwar, A. Kalia, N. Singh and D. Narang (2016). Isolation of endophytic actinomycetes from Syzygium cumini and their antimicrobial activity against human pathogens. J. Appl. Nat. Sci., 8: 416-422.

Stone, J.K., W.B. Charles and F.W. James (2000). In "An Overview of Endophytic Microbes: Endophytism Defined". Dekker, New York, pp. 3-5.

Strobel, G.A. (2003). Endophytes as sources of bioactive products. Microbes Infect., 5: 535-544.

Strobel, G.A., R.V. Miller, C. Martinez-Miller et al. (1999). Cryptocandin, a potent antimycotic from the endophytic fungus Cryptosporiopsis cf quercina. Microbiology, 145: 1919-1926.

Taechowisan, T., C. Lu, Y. Shen and S. Lumyong (2005). Secondary metabolites from endophytic Streptomyces aureofaciens CMUAc130 and their antifungal activity. Microbiology, 151: 1691-1695.

Taechowisan, T., C. Lu, Y. Shen and S. Lumyong (2007). Antitumor activity of 4-arylcoumarins from endophytic Streptomyces aureofaciens CMUAc130. J. Cancer Res. Ther., 3: 86-91.

Taechowisan, T., N. Chuaychot, S. Chanaphat, A. Wanbanjob and Y. Shen (2009). Antioxidative and inhibitory activity on nitric oxide production of flavonoids from Streptomyces sp. Tc052J. Pharm. Res., 2: 313-316.

Tanvir, R., I. Sajid and S. Hasnain (2014). Larvicidal potential of Asteraceae family endophytic actinomycetes against Culex quinquefasciatus mosquito larvae. Nat. Prod. Res., 28: 2048-2052.

Tawde, K.V., R.N. Gacche and M.M. Pund (2012). Evaluation of selected Indian traditional folk medicinal plants against Mycobacterium tuberculosis with antioxidant and cytotoxicity study. Asian Pac. J. Trop. Dis., 2: 685-691.

Thomson, R.H. (1997). In "Naturally Occurring Quinones IV: Recent Advances" $4^{\text {th }}$ Ed. Blackie Academic and Professional, London; New York.

Yadav, M., A. Yadav and J.P. Yadav (2014). In vitro antioxidant activity and total phenoliccontent of endophytic fungi isolated from Eugenia jambolana Lam. Asian Pac. J. Trop. Med., 7S1: S256-61.

Yildirim, A., A. Mavi and A.A. Kara (2001). Determination of antioxidant and antimicrobial activities of Rumex crispus L. extracts. J. Agric. Food Chem., 49: 4083-4089.

Zhu, H., S. Jiang, Q. Yao, Y. Wang, M. Chen, Y. Chen and J. Guo (2011). Streptomyces fenghuangensis sp. nov., isolated from seawater. Int. J. Syst. Evol. Microbiol., 61: 2811-2815. 


\section{القدرات المضادة للميكروبات والأكسدة للنابوت الداخلي الأكتينومايسيتس الأيس

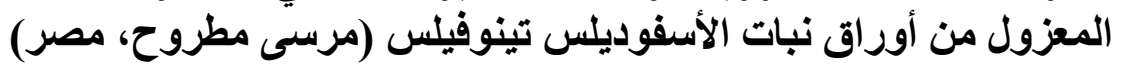

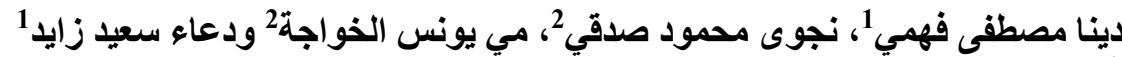

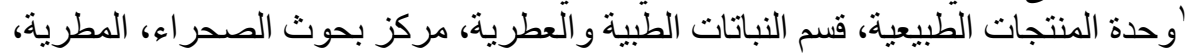
القاهرة، مصرة المنجات

"قَّم النبات و الميكروبيولوجى، كلية العلوم، جامعة الأز هر (فرع البنات)، القاهرة، مصر

الهدف من الدر اسة تقييم النشاط المضاد للميكروبات والنشاط الإلتهامي (الكاسح) للشقائق

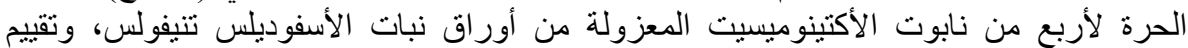

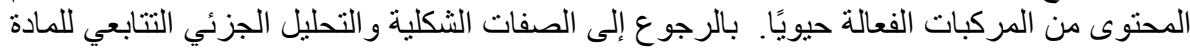
Streptomyces تعرف 16S rDNA للأكتينوميسيت Act fenghuangensis (GIMN4.003T) تقييم الجهد المضاد لكل العزلات ضد السلالات الممرضة من البكتيريا والفطريات، وأيضًا تقييم

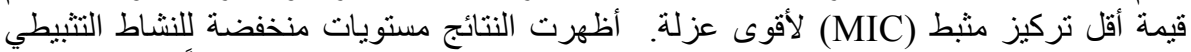

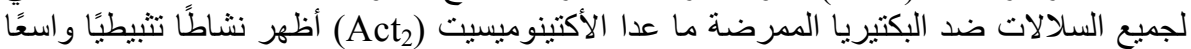

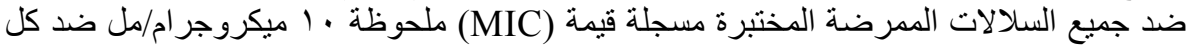

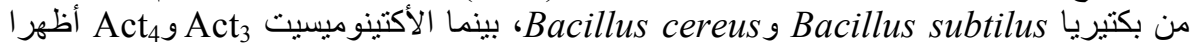

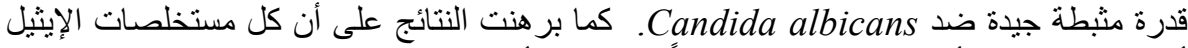

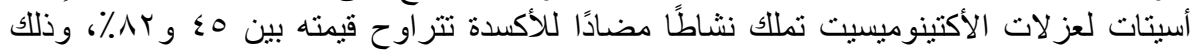

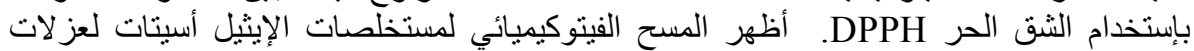

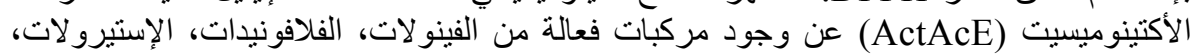
الأحماض الدهنية، الأنثر اكينون و النفتاكينون.

Egyptian J. Desert Res., 66, No. 2, 373-386 (2016) 